\title{
Examination of the Opinions of Physical Education and Sports Teachers Working in Private Schools on the Approach of Education, Teaching and Management
}

\author{
Abdullah Bingölbalı (Corresponding author) \\ Faculty of Sport Sciences, Frrat University, Turkey \\ Tel: 90-507-404-6812Ｅ-mail: bingolbali@gmail.com \\ Cumaali Yavuz \\ Faculty of Sport Sciences, Frrat University, Turkey \\ Tel: 90-538-785-5353Ｅ-mail: cyavuz@firat.edu.tr
}

Received: October 28, 2021 Accepted: November 27, 2021

Published: December 13, 2021

doi:10.5296/jei.v7i2.19128 URL: https://doi.org/10.5296/jei.v7i2.19128

\begin{abstract}
The number of private schools in our country is increasing day by day and they are in demand. As a result of this, an education sector with its own unique working conditions and standards has formed. Based on this situation, it is important for the quality of education to reveal the current situation of private schools regarding the education process from a real, impartial, and different perspective. The aim of this study is to determine the remarks of Physical Education teachers working in private schools on education, training, management processes and parent-student relations in Private Schools. The sample group of this study consists of 20 Physical Education teachers working at private schools in Turkey (in the province of Elazig) and selected according to the criterion sampling method, one of the purposive sampling methods. In the research, semi-structured and in-depth interviews were conducted with 20 teachers by using the phenomenology pattern, one of the qualitative research methods. The collected data were analyzed and themed by content and descriptive analysis methods. It has been determined that the assessment and evaluation made in these schools are not objective and do not reflect the truth. However, it has been observed that all kinds of opportunities are offered in order to increase the learning motivation of students in private education institutions, technological opportunities are high and they are used in the
\end{abstract}


field of education, all kinds of sports and social activities are carried out and these have a positive effect on teaching methods and processes It has been determined in these schools that private lessons are given to some students for money and this is common. It has been observed that this situation affects the perspectives of the teachers towards the students and the students towards the teacher and the lesson and some teachers that direct students to learn formulas and memorize them instead of focusing on their thinking strategies and skills. Emphasis is placed on the selection of school administrators. In addition, it has been determined that parents are closely interested in their students and this situation affects student success closely.

Keywords: Education, Sports, Private school, Physical education and sports teacher

\section{Introduction}

In our time, the rapid change process that occurs in every field also closely affects the expectations and demands of people from educational institutions. Schools are institutions that are directly effective in the development of countries and integrating with the concept of education and educational service (Açıkalın, 1998: Arslan et al., 2006). When the issue is considered from this point of view, it is seen that bringing the desired attitudes, behaviors and educational characteristics of the societies to the individuals is one of the reasons for the existence of the schools. States have begun a quest to alleviate the burden of educational institutions, which are of great importance for their future, to increase their quality, and to offer equal education opportunities to all segments and individuals. One of these quest is the opening of private education institutions and schools as well as public schools. In this way, it is aimed that the citizens with the available means meet the education expenses with their own means, that the burden of the state is alleviated, thus increasing the quality of education by transferring more resources to those who have limited opportunities.

Educational institutions whose expenses are not covered by the state budget are defined as private schools. Apart from public schools, the owners of these schools, which provide education and training from kindergarten to university, may be individuals or charities (Uygun, 2003). In our age, these institutions, which are owned by both domestic and foreign institutions and private individuals, are educational institutions that provide formal education for a certain fee under the control and supervision of the Ministry of National Education and must act within the frame of legal regulations. Today, private schools are becoming widespread and more popular in our country. Concordantly the number of employees is also increasing who has working in these educational institutions. As a result of this, an education sector with its own unique working conditions and standards was formed. It can be said that the satisfaction of parents and students is largely effective in the formation of these conditions (Kaya, 2009). It is extremely important that organizations have the power to influence and their image (Demiröz, 2014; Kılıçaslan, 2011).

It is stated by all segments of society that the image and quality of public schools in Turkey are gradually decreasing, the education and training in these schools has become increasingly ineffective, and far from meeting the expectations of students, parents and society (Arslan et al., 2006; Nartgün \& Kaya, 2016). Although there is interest and demand in the society 
towards private education institutions, there are also negative evaluations against these institutions. Negative approaches about private schools like "They are institutions that support the capitalist order and serve the children of the rich. It eliminates the equality of opportunity in education and leads to unfair competition. It raises foreign admirers, conservative and even reactionary individuals who are contrary to the type of people desired by the States and Societies." are also exhibited about these educational institutions (Uygun, 2003). Based on this situation, the opinions of the teachers who worked in these educational institutions are important in order to reveal the current situation of private schools regarding the education process from a real, impartial and different perspective. In this context, questioning the experiences of Physical Education Teachers working in Private Schools regarding education, training, management processes and parent-student relations is the main problem of this research. It is thought that such a study will make important contributions to the field in terms of providing scientific data and enabling international comparisons to the researches on the education, training and management processes of physical education teachers working in private schools in our country. On the other hand, the research also allows the Turkish Education System to be evaluated from a different perspective by Physical Education teachers working in private schools. Thus, the evaluations of teachers are likely to contribute to policy makers and practitioners in terms of eliminating deficiencies in the education system, making improvements and developing positive aspects.

The aim of this study is to determine the remarks of Physical Education teachers working in private schools in Turkey (in the province of Elazig) on education, training, management processes and parent-student relations in Private Schools.

\section{Method}

\subsection{Model of the Research}

In the conduct of this research, the case study method, which is one of the qualitative research methods, was used. The most basic features of the qualitative case study are investigating a situation in depth and understanding its causes and consequences (Y1ldırım \& Şimşek, 2011). It was aimed to benefit from, the experiences of the physical education teachers working in private schools in the province of Elazig in Turkey, on the education, teaching, management process and parent-student relations in Turkey. The phenomenology pattern was used in this study (Fraenkel \& Wallen, 2009; Patton, 2014).

\subsection{Working Group}

According to the criterion sampling method, which is one of the purposive sampling methods, 20 Physical Education teachers working constitute the study group who are working in different education levels of private schools in Elazig province of Turkey in the 2020-2021 academic year (Tarhan, 2015). 20 teachers were interviewed in the study dua to data were repeated, and saturation is reached. According to Merriam (2018), data collection ends when it is considered that saturation is reached as a result of repetition of data in qualitative research and that new data cannot be reached. For this reason, data collection was terminated after 20 teachers. The information of the participants regarding gender, age, education level, 
professional seniority and private school experience is presented in Table 1.

Table 1. Distribution of participants according to various variables

\begin{tabular}{|l|l|l|l|l|l|}
\hline Participant No. & Gender & Age Range & $\begin{array}{l}\text { Private School } \\
\text { Experience }\end{array}$ & $\begin{array}{l}\text { Educational } \\
\text { Level }\end{array}$ & $\begin{array}{l}\text { Professional } \\
\text { Seniority }\end{array}$ \\
\hline T1 & Male & $45-55$ & 15 & Bachelor & 20 \\
\hline T2 & Male & $35-45$ & 16 & Bachelor & 16 \\
\hline T3 & Male & $35-45$ & 5 & Bachelor & 20 \\
\hline T4 & Male & $35-45$ & 11 & Bachelor & 11 \\
\hline T5 & Male & $35-45$ & 10 & Bachelor & 10 \\
\hline T6 & Female & $25-35$ & 6 & Bachelor & 6 \\
\hline T7 & Male & $25-35$ & 8 & Bachelor & 10 \\
\hline T8 & Male & $35-45$ & 5 & Master & 5 \\
\hline T9 & Male & $35-45$ & 3 & Bachelor & 3 \\
\hline T10 & Male & $25-35$ & 9 & Bachelor & 9 \\
\hline T11 & Male & $35-45$ & 7 & Bachelor & 7 \\
\hline T12 & Female & $35-45$ & 8 & Bachelor & 20 \\
\hline T13 & Male & $25-35$ & 8 & Bachelor & 8 \\
\hline T14 & Male & $25-35$ & 5 & Master & 11 \\
\hline T15 & Male & $35-45$ & 3 & Bachelor & 13 \\
\hline T16 & Female & $35-45$ & 6 & Bachelor & 15 \\
\hline T17 & Male & $35-45$ & 2 & Bachelor & 8 \\
\hline T18 & $25-35$ & 4 & Bachelor & 4 \\
\hline T19 & $25-35$ & 1 & Bachelor & 6 \\
\hline T20 & $25-35$ & 5 & Bachelor & 7 \\
\hline
\end{tabular}

\subsection{Data Collection and Analysis}

In the study, a semi-structured interview form developed by the researchers was used as a data collection tool and data were collected through interviews (Balc1, 2009). While creating the semi-structured interview form, the relevant literature was scanned in detail; The opinions of 4 academicians who are experts in the field of educational administration and supervision and teachers working in private schools were consulted. The questions in the interview form were rearranged and the form was given its final form in a way that is suitable for the purpose 
of the research, understandable and applicable as a result of the examination of the experts and the pre-application with 2 teachers. Each interview lasted approximately 20-40 minutes and the interviews of the participants were recorded with audio recording. In the analysis of the data, the frequency of each view was found by using the content analysis technique. Voice recordings were transferred to a computer, decoded and Nvivo 10 package program was used for analysis. Under the research questions the views of the participants were transformed into themes. In addition, descriptive analysis technique was used in the analysis of the data obtained during the interview, by making direct quotations from time to time in order to draw attention to the opinions of the participants (Türnüklü, 2000)

\subsection{Validity and Reliability of the Research}

In order to ensure validity and reliability in a qualitative research, credibility, transferability, consistency and confirmability strategies should be used (Shenton, 2004). Credibility is related to the internal validity of the research (Lincoln \& Guba, 2013). After the interview forms were developed they were presented to the expert opinion for credibility, and as a result of these opinions, necessary arrangements were made and the form was given its final shape. In addition, while presenting the findings, some of the participant's views were included in the form of direct quotations. Transferability is related to the external validity and generalizability of the research. Within the scope of this study, the purposeful sampling method was used to ensure external validity, and at the same time, each stage of the study such as information about the participants, data collection and analysis were explained in detail. Consistency is related to the repeatability and reliability of the research. Therefore, the data obtained for this purpose were first analyzed by each researcher individually, then the analyzes were checked together and common themes were determined (Creswell, 2012). For this reason, the in-depth analysis process was spread over a period of approximately two months, and the analyzes were repeated until a consensus was reached on the themes. Emphasis is placed on the objectivity of research with confirmability. The final version of the themes and codes were sent to the experts and confirmed. Since it was deemed ethically appropriate to keep the identities of the participants in the study confidential, the teachers were abbreviated as T1, T2, . T20 in the presentation of the findings.

\section{Results}

\subsection{Opinions on the Education-Training Process}

The views of Physical Education teachers working in Private Schools on the education-training process are shown in Figure 1 as themes. 


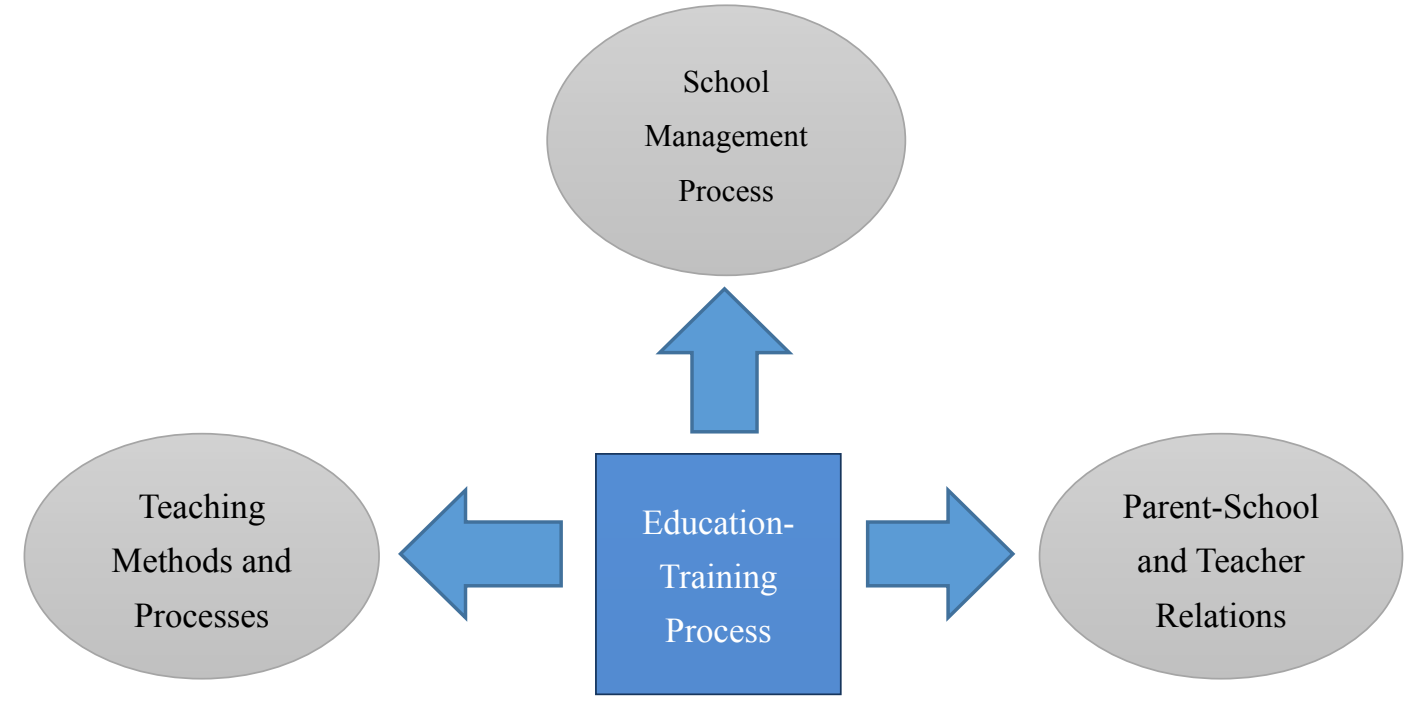

Figure 1. Views on the education-training process

As seen in Figure 1, the opinions of the participants on the theme of the education-teaching process in Private Schools were evaluated in three sub-themes: Parent-School-Teacher Relations, School management, Teaching processes and methods. These sub-themes are explained below

\subsection{Teaching Methods and Processes}

The views of Physical Education and Sports teachers on Teaching Methods and Processes in Private Schools are shown in Figure 2 as themes and sub-themes. 


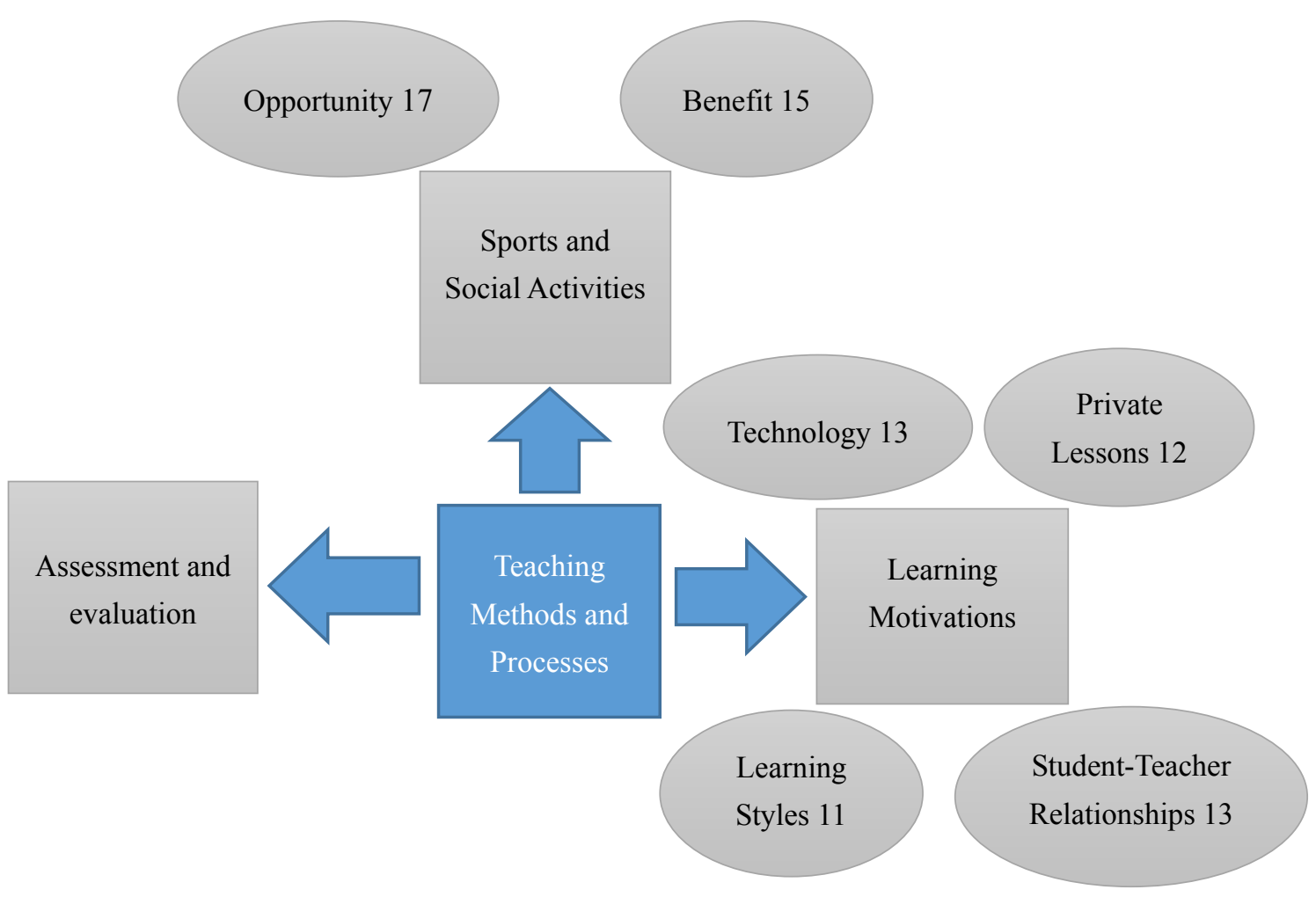

Figure 2. Remarks on teaching methods and processes

In consequence of the interviews with the participants about the teaching methods and processes in private schools; It is seen in Figure 2, that the themes of measurement and evaluation, sportive and social activities, learning motivations and sub-themes belonging to these themes, benefits, opportunities, technology, private lessons, learning styles, student-teacher relations are formed. These sub-themes are explained below.

\subsection{Assessment and Evaluation}

Physical Education teachers, who evaluated the assessment and evaluation system in private schools, stated that the assessments made in these schools were not objective and did not reflect the truth, the grades were exaggerated in order not to lose the student because they were private schools, the level of the students was determined well, but the reflection of this on the grade was exaggerated. In this context, sample sentences expressing the views of teachers by quoting directly are presented below.

"I don't think there is objective evaluation, but more interest and relevance is shown in terms of content." (T4).

“There is no objectivity in Assessment and Evaluation. Grades are raised." (T9).

\subsection{Learning Motivations}

The views of Physical Education and Sports teachers on the learning motivation of students in private schools are shown in Figure 3 as themes and sub-themes. 


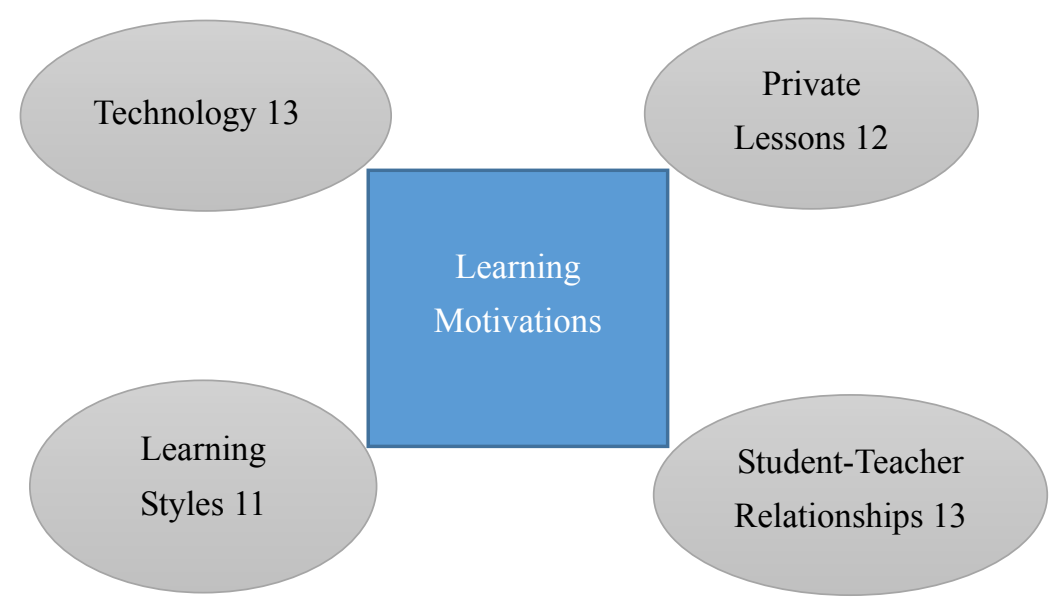

Figure 3. Views on students' learning motivation

In Figure 3, it is seen that the sub-themes of Technology, Private lessons, Learning styles, Student-Teacher relations were formed as a result of the interviews with the participants about the theme of Learning Motivation of Students in Private Schools. The participants stated that these schools have sufficient opportunities and facilities for learning, and that all kinds of opportunities are provided to increase the learning motivation of the students, and that the awareness of the families is effective in the learning-orientedness of the students. Within this context, they stated that the fact that the classroom teachers and guidance services are very interested and active affects the motivation of the students positively. However, contrary to these views, it was emphasized by some participants that learning motivation of students is low because they do not have grade anxiety, and that the children of families with high financial status prefer rote-based learning rather than learning-oriented. These sub-themes are explained below.

Technology: Physical Education and Sports teachers stated that the technological opportunities in private schools are high and they are widely used in the field of education, which increases student motivation. In this context, direct quotation of sample sentences expressing the views of teachers are presented below.

"Student and parent satisfaction is very important in private schools. After all, since these are educational places established to make money, they have to follow and apply technology closely in order not to lose their students." (T11).

"The technological means of these schools are wide because if they do not offer these services, they cannot compete with other schools." (T18).

Private Lessons: Participants stated that private lessons are common in these schools and this situation affects teachers' perspectives towards students, students towards the teacher and the lesson, and although it has positive effects on students, it reduces their motivation to learn and interest in lessons. Sample sentences about opinion of the teachers on this issue is presented below. 
"I have seen that private lessons are given very intensively in almost all of the private schools where I work. I think this is overrated by parents and students and negatively affects interest of students to school and lessons." (T3).

"Private lessons are very common, but I personally do not view this issue very positively. Because it causes negative attitudes such as disrespect and indiscipline towards teachers and school in students" (T15).

Learning Styles: Some of the Physical Education teachers stated that since the students do not have grade anxiety in private schools, they are motivated to the lessons and follow the learning-oriented lessons. They stated that the level of awareness of the family and the work of the guidance services are also effective in this regard. However, contrary to these views, it was also emphasized that children with more financial means choose the way of learning based on rote, and some teachers' direct students to memorize formulas instead of focusing on their thinking strategies and skills. In this context, sample sentences belonging to teachers are presented below.

"Student parents are conscious, closely monitor learning status of their children and are in constant contact with the guidance service." (T14).

"Since the income levels of the children in private schools are high, they are always used to being ready, this makes them rote learning." (T9).

Student-Teacher Relationships: Participants stated that there are very close relationships based on respect and understanding between students and teachers in private schools, and this situation positively affects their learning motivation. However, it was also stated that some students abused this situation, but the number of them was very low. A sample sentence about the opinion of teachers on this subject is presented below.

"Although there are sometimes minor problems, we definitely have a high level and close relationship with the students. When this happens, both us and the students are being happy, which is bringing success." (T19).

\subsection{Sports and Social Activities}

The views of Physical Education and Sports teachers on Sports and Social Activities in Private Schools are shown in Figure 4 as themes and sub-themes. 


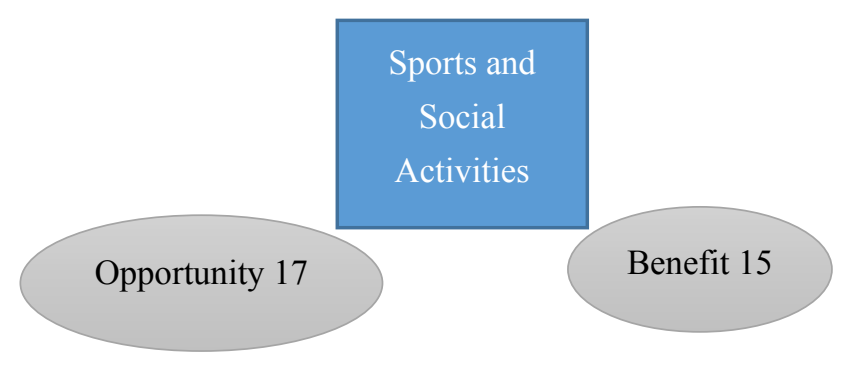

Figure 4. Views on sports and social activities

In Figure 4, it is seen that the sub-themes of Possibility and Benefit were formed as a result of the interviews with the participants about the theme of Sporting and Social activities in private schools. These themes are described below.

Opportunity: Physical Education and Sports teachers stated that there are many Sportive and Social opportunities in private schools, all kinds of sportive and social activities are carried out, and parents and students want these activities very much. A sample sentence about the opinion of teachers on this issue is presented below.

"Our opportunities for sportive and social activities are very wide, we can carry out all kinds of activities. In fact, these opportunities are the reason for preference when choosing private schools. When parents first come to school, they first want to be informed about such activities." (T8).

Benefit: Participants stated that Sportive and Social activities in schools affect teaching methods and processes positively and are very useful in increasing student and school success. A sample sentence about the opinion of teachers on this issue is presented below.

"The most important thing in private schools is social and sports activities. These activities are done in large numbers, which makes parents and students happy and enchain them to the school. Thus, both school and student success increase, and this is where it differs from public schools" (T1).

\subsection{School Management Process}

The views of Physical Education and Sports teachers about the School Method and Process in Private Schools are shown in Figure 5 as themes and sub-themes. 


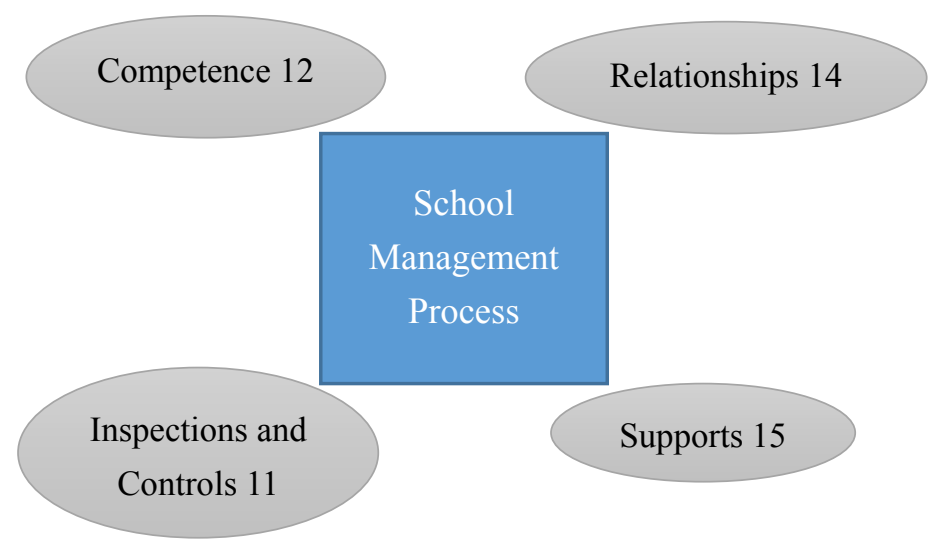

Figure 5. Views on school management process

In Figure 5, it is seen that the sub-themes of competence, relationships, supports, supervision and controls were formed as a result of the interviews with the participants about the school management process in private schools. These sub-themes are explained below.

Competence: The participants stated that due to the commercial concerns of private schools and the vision of representing the school, they are meticulous when choosing the administrators, their personalities, knowledge, experience, and public relations are considered. Sample sentences about the opinions of the participants on this issue are presented below.

"Private schools are very sensitive about administrators. They try to choose the best in their fields. In the state, many different factors come into play and the sensitivity shown by private schools is not shown." (T2).

Relationships: Physical Education and Sports teachers stated that school administrators are in close relations with teachers, parents, and students, they care about teamwork, and the relations are cultivated due to being a private school. Sample sentences about the opinions of the participants on this issue are presented below.

"Employee and management relations are very close, but continue cultivatedly with the atmosphere of being a private sector." (T20).

"The concept of discipline and shift is meticulously applied in relationships." (T16).

Supports: Teachers stated that school administrations closely support all activities concerning students and can manage time well. In addition, it was also stated by the participants that the support of such activities and activities stemmed from the general vision of the school. Sample sentences about the opinions of the participants on this issue are presented below.

“All social activities in schools are encouraged by the administrators.” (T17).

"All activities in favor of students are supported materially and morally." (T12).

Inspections and Controls: The participants stated that the school administrations carried out the inspections and controls on time, and when any problems were seen, it was tried to be 


\section{Macrothink

resolved through a meeting instead of one-to-one meetings. In addition, it was also stated by the participants that audits and controls are not important, that they are only for show, and that employees give all their energies to their jobs due to lack of job guarantee arising from being private. Sample sentences about the opinions of the participants on this issue are presented below.

"Inspections and controls are carried out on time and no concessions are made to the employees." (T5).

"Troubles are tried to be resolved through meetings, but all the controls are all vanity, the main purpose is making advertisement." (T3).

\subsection{Parent-School and Teacher Relations}

The views of Physical Education and Sports teachers working in Private Schools on Parent-School and Teacher relations are shown in Figure 6 as themes.

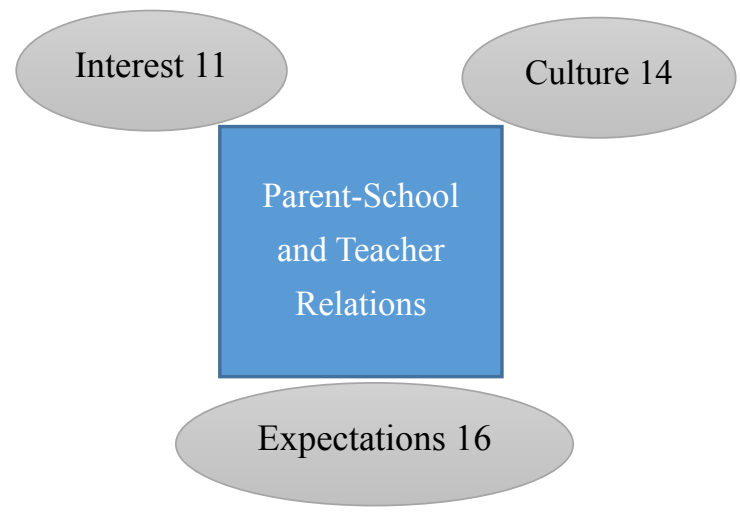

Figure 6. Views on parent-school and teacher relationships

In Figure 6, as a result of the interviews with the participants about the theme of Parent-School and Teacher Relations in Private Schools, it is seen that the sub-themes of Interest, Expectation and Culture are formed. These sub-themes are explained below.

Interest: The participants stated that the parents in private schools are closely interested in the situation of their students and they constantly talk to the school administration and teachers, but sometimes they despise the teachers and the school because they pay the school fees. Sample sentences about the opinions of the participants on this issue are presented below.

"Most of the parents are respectful and caring. They try to keep a close eye on their children." (T6) 
"Teachers are in contact with the parents, but some parents think that they can do whatever they want because they pay for private schools. Schools are worried about next year enrollments. Although this is undesirable, it causes some adversity experiences." (T10)

Expectation: Physical Education and Sports Teachers stated that school parents have very high expectations from private schools and teachers, therefore they have very tight communication with the teacher and the administration. Sample sentences about the opinions of the participants on this issue are presented below.

"Parents have very high expectations from the school and teachers, so they come to school frequently and meet with the guidance service and teachers one-to-one." (T12)

"The high expectations of the parents motivate both the school administration and the teachers to work harder." (T8)

Culture: The participants stated that the culture level and awareness level of the parents is an important factor in parent-school and teacher relations, and this closely affects student success. Sample sentences about the opinions of the participants on this issue are presented below.

"The fact that parents are cultured and reflect this on their relationships positively affects the motivation of school administrators and teachers about education." (T4)

"Conscious parents always know where and how to behave and they warn their children to behave in this way, so that thoughts of students towards the school and the teacher change in a positive way. That brings success." (T18)

\section{Discussion and Conclusion}

Physical Education teachers stated that the evaluations made in private schools are not objective and do not reflect the truth, since they are a private school the grades are exaggerated in order not to lose the student, the levels of students are well determined, but the reflection of this on the grades is exaggerated. It has been observed that other studies conducted in this context support our study. For example, Özenç (2013) found in his study that the average of teachers working in private schools is higher than teachers working in public schools. In their study, Asma et al. (2018) stated that the private school teachers they interviewed were not put under any pressure, but that there was an unwritten tendency to give high grades to students in the institutions they worked and they were worried that a teacher who gave low grades might have problems with parents and school management.

The participants stated that all kinds of opportunities are offered to increase the learning motivation of the students in private education institutions, that the awareness of the families is effective in being learning-oriented students, and that these schools have sufficient opportunities and facilities for learning by doing and experiencing. Within this context, they stated that the fact that the classroom teachers and guidance services are very interested and active affects the motivation of the students positively. However, contrary to these views, it was emphasized by some participants that motivation of students to learn was low and their 
interest in the lessons decreased because they did not experience grade anxiety, and that the children of families with high financial status preferred rote-based learning rather than learning-oriented. In the study conducted by Ünsal et al. (2019) on this subject, it was stated that the physical infrastructure of private schools is better than public schools, so they implement their training programs more effectively. They concluded that parents are closely interested in their children and this contributes positively to the implementation of the training program. Pehlivan (2004) also emphasized in his study that the equipment and physical characteristics of a school are important factors affecting the training program and motivation. Bumen et al. (2014) also states that social, economic and cultural characteristics are among the factors affecting learning motivations.

Physical Education and Sports teachers stated that the technological opportunities in private schools are high and they are used intensively in the field of education, which increases student motivation. In line with this study, Seferoğlu (2015) stated in his research that the situation is generally at a good level when we look at the data on information and communication technologies ownership in schools of our country and Private schools play a leading role in this regard. In this context, Akpınar et al. (2005), in their study, that there was a significant difference between the frequency of use of laboratory equipment, overhead projector, computer, etc. In their research, Çobanoğlu (2011), and Dikbaş (2008) pointed out that among the reasons why there is a demand for private schools, the schools have high physical standards and they follow international approaches and technology in the field of education. In addition, the participants stated that private lessons are common in these schools and this affects perspectives of teachers towards students, students towards teachers and lessons, and decreases their learning motivation andinterest in lessons (Aydin et al., 2019). In this context, Çiftçi and Çağlar (2014) pointed out in their study that the socio-economic level of families affects not only enrollment, participation and completion of school (Tansel, 2002; Tansel \& Bircan, 2006), but also the level of academic achievement of students. Some of the Physical Education teachers stated that since the students do not have grade anxiety in private schools, they are motivated to the lessons and follow the learning-oriented lessons and that the awareness level of the family and the guidance services are effective in this regard. However, contrary to these views, it is also emphasized that children with high financial means choose the way of learning based on rote, and since it is a private school, some teachers direct students to memorize formulas instead of focusing on the thinking strategies and skills of students in order to gain the satisfaction of parents, students and school administration in a short time. Bil (2018) emphasized that private schools manage the learning process better than public schools and this affects learning styles. In this context, Aydın et al. (2019) stated in their study that foreign teachers that their Turkish colleagues had a consideration of education based on rote learning. Bacıŏlu et al. (2017), and Karaküçük (2010) emphasized in their research that the guidance service of private schools is better in terms of both spatial and equipment.

Participants stated that there are generally very close relationships based on respect and understanding between students and teachers in private schools, and this situation positively affects their learning motivation. However, it was also stated that some students abused this 
situation from time to time, but the number of them is very small. Yenilmez and Özbey (2006) stated that it is the duty of teachers to encourage students and make them believe that they can be successful, and that they should use various materials and keep their motivation high in order to make the lessons enjoyable. Again, Aktan (2012) emphasized in his study that teachers should encourage students to ask questions, explore opportunities, suggest alternatives, and develop criteria for themselves.

Physical Education and Sports teachers stated that there are many Sportive and Social opportunities in private schools, all kinds of sports and social activities are carried out, parents and students want these activities very much. In addition, they stated that Sportive and Social activities in schools affect teaching methods and processes positively and are very useful in increasing student and school success. In this context, Akdoğan (2014), Nartgün and Kaya (2016) stated that the diversity of social and sports activities in schools, the success of school sports teams, and the sensitivity of school to social responsibility projects increase the rate of preference of these schools.

The participants stated that due to the commercial concerns of private schools and the vision of representing the school, they are meticulous when choosing the administrators, their personalities, knowledge, experience, and public relations are considered. Tümkaya and Asar (2017) also stated that the type of school does not have a significant effect on managerial competencies, and that the understanding of the manager with leadership characteristics is now dominant instead of the classical management perception in public and private schools. However, there are also different research findings. For example, in a study conducted by Uysal (2001) aiming to determine the managerial and leadership behaviors of private and public primary school principals, it was determined that there was a significant difference between managerial and leadership behaviors. Furthermore, Tinmaz (2000) concluded in his research that private primary school administrators are more effective in leadership.

Physical Education and Sports teachers stated that school administrators have close relationship with teachers, parents and students. They stated that the administrators care about teamwork and that the relations are cultivated due to being a private school. In this context, Çalışkan and Ayık (2015), and Özdayı (2004) stated in their studies that efforts to strengthen the communication between teachers and families can increase the success of students in school and prevent disciplinary problems at school. In their study, Arslan and Nural (2004) emphasized that the school administration, who wants to achieve success in education, should give importance to the relationship between parents and teachers and that the participation of parents in school activities increases student success.

The teachers who participated in the research stated that school administrations closely support all activities concerning students and can manage time well. In addition, it was stated by the participants that the support of such activities stemmed from the general vision of the school. In this direction, Aydoğar and Yirci (2020) found that the average score of school administrators in private schools is higher than that of public school administrators in their research on innovation management and support skills of school administrators.

The participants stated that the school administrations carried out the inspections and controls 
on time, and when any problems were seen, it was tried to be resolved through a meeting instead of one-to-one meetings. In addition, it was also stated by the participants that audits and controls are not important, that they are only for show, and that employees give all their energies to their jobs due to lack of job guarantee arising from being private. Treslan (2008), Gündüz (2012) emphasized that teachers need guidance and help in solving their educational problems and increasing their productivity, and that this help and guidance can be provided by the administrations in the most effective way. Furthermore, the participants of research stated that the parents in private schools are closely interested in the situation of their students and they constantly talk to the school administration and teachers, but from time to time there are problems with the point of view of the teacher and the school due to the payment of fees to the school. Aksu (2008) emphasized that the parent's approach and guidance to their child has a very important place in the education of child, and therefore parents, school, and teacher should be in constant cooperation.

Physical Education and Sports Teachers stated that the expectations of school parents from private schools and teachers are very high, so they communicate very closely with the teacher and the administration. In addition, the participants stated that the cultural level and awareness level of the parents is an important factor in parent-school and teacher relations, and this closely affects student success. Regarding this issue, Bursalığlu (2005), and Kaya (2012) and Özkan (2018) emphasized that the main behaviors that parents expect from school administrators are establishing good relations, dealing with students, getting to know parents, and helping them.

Considering the results of the above-mentioned scientific studies, which are in line with our study and have similar characteristics, it can be said that they support the results of our study.

\section{Suggestions}

Physical Education and Sports teachers shed light on some of the problems of the Turkish Education System from a different perspective with the experiences they gained from the private schools they work in. Suggestions developed in line with the data obtained from this study are listed below.

(1) The participants stated that the measurements and evaluations made in private schools are not objective and do not reflect the truth. Since students going to private and other public schools will take the same exams, the effect of school success scores on exam scores should be removed in order to eliminate injustice while calculating exam scores. In addition, it can be ensured that all exams are conducted with a central system.

(2) Physical Education Teachers participating in the research stated that the technological opportunities in private schools are high and they are widely used in the field of education and this brings success. In order to offer these technological opportunities to public schools, studies should be carried out continuously and should be kept on the agenda in order to provide support from local businessmen, volunteer donors, municipalities and other public institutions.

(3) The participants emphasized that there are many Sportive and Social opportunities in 
private schools, all kinds of sportive and social activities are carried out, and that Sportive and Social activities in these schools affect the teaching methods and processes positively. For this reason, it should be preferred that at least public schools be built by considering such possibilities from now on.

(4) Furthermore, Tinmaz (2000) concluded in his research that private primary school administrators are more effective in leadership. the participants stated that private schools very meticulously when choosing administrators. While selecting administrators for public schools, it should be ensured that merit is emphasized, not political preferences.

(5) The teachers stated that the cultural and consciousness level of the parents are an important factor and that this closely affects the success of the students. In order to raise the level of awareness of the parents in other schools, all kinds of activities that ensure the active participation of the parents and are prepared together can be organized by the schools.

\section{References}

Akdogan, H. (2014). Parents' expectations from school and teachers for student success (Master's thesis, Institute of Social Sciences, Fatih University, Istanbul).

Akpınar, E., Aktamış, H., \& Ergin, Ö. (2005). Student views on the use of educational technology in science lessons. The Turkish Online Journal of Educational Technology, 4(1), 93-100.

Aksu, S. (2008). The expectations of the parents of the students in the 2nd level of primary education from the Painting-Business course (Master's thesis, Uludag University, Bursa).

Aktan, S. (2012). Relationship Between the Academic Success, Self-regulation Learning Skills, And Motivations of 5th Grade Students and Teaching Styles of Teachers (Doctoral thesis, Institute of Social Sciences, Department of Educational Sciences, TC Balıkesir University, Balikesir).

Arslan, H., Seller, A., \& Kuru, M. (2006). Investigation of the Effectiveness of Public and Private Primary Schools. Tendency and Science, 31(142), 15-25.

Arslan, U., \& Nural, E. (2004). The Importance of School-Family Cooperation in Preschool Education, Journal of National Education, 162, 99-108.

Asma, M., Camlier, H., Soyturk, M., Balci, T., \& Camlier, H. (2018). An Investigation on Alternative Measurement and Evaluation in Physical Education and Sport Teaching. Sakarya University Journal of Education, 8(3), 37-62. https://doi.org/10.19126/suje.398201

Aydın, İ., Toptaş, B., Güner Demir, T., \& Erdemli, Ö. (2019). Being a Foreign Teacher in Private Schools in Turkey: Views on Education, Teaching and Management Approach Education and Science Journal, 44(200), 1-22.

Aydoğar, N., \& Yirci, R. (2020). Comparison of Innovation Management Skills of Public and Private School Administrators: A Quantitative Research. Istanbul Commerce University 
Journal of Social Sciences, 19(39), 1286-1308. https://doi.org/10.46928/iticusbe.804129

Bacıoğlu, S. D. I., Kocabıyık, O. O., \& Malkoç, A. (2017). Psychological Guidance and Counseling Students' Evaluation of Guidance Services in Schools. Turkish Psychological Counseling and Guidance magazine, 48(7), 45-62.

Balci, A. (2009). Research in the social sciences (7th ed.). Ankara: Pegem A Publishing.

Bil, E. (2018). Relatıonship Between the Concepts of Learning Organization, Organızatıonal Trust and Job Satisfaction of High Schools (pp. 156-160, Doctoral thesis, Institute of Educational Sciences, Department of Educational Administration and Policy, Ankara University, Ankara).

Bümen, N. T., Age, E., \& Stars, D. G. (2014). Factors affecting dedication and commitment to education in Turkey, Theory and Practice of Educational Sciences, 14(1), 203-228. https://doi.org/10.12738/estp.2014.1.2020

Bursalığlu, Z. (2010). The New Structure and Behavior of School Administration. Ankara: Pegem A Publishing.

Ciftci, C., \& Caglar, C. (2014). The effect of families' socio-economic characteristics on student achievement: Is poverty destiny? International Journal of Human Sciences, 11(2), 155-175.

Çobanoğlu, A. (2011). Evaluation of the school image of public and private primary schools according to the opinions of teachers and parents (Published Master's thesis, Marmara University, Istanbul).

Creswell, J. W. (2012). Educational Research: Planning and Evaluating conducting quantitative and qualitative research (4th ed.). New Jersey, NJ: Pearson Ed. Inch.

Dikbaş, I. (2008). Parent expectations and satisfaction levels, the example of private foundation schools (Unpublished Master's thesis, Yeditepe University, Istanbul).

Diligent, N., \& Sober, A. (2015). Parent-Teacher Association (PTA) and Communication with Parents. Journal of Ahi University Institute of Social Sciences, 1(2), 69-82.

Fraenkel, J. R., \& Wallen, N. E. (2009). How to design and evaluate research in education. New York, NY: The McGraw-Hill Companies.

Gündüz, Y. (2012). Inspection Requirement in Educational Organizations: A Theoretical Study. Dumlupınar University Journal of Social Sciences, 34.

Karakücük, S. (2010). Examining the physical/spatial conditions of school guidance services (in the context of guidance teachers' spatial perceptions). Journal of the Social Sciences Institute, 28(1), 421-440.

Kaya, E. (2009). The Relationship Between Private School Teachers' Perceptions of Emotional Labor Behavior and Job Satisfaction and Job Stress (Master's thesis, Institute of Social Sciences, Department of Industrial and Organizational Psychology, TC Maltepe 
University, Istanbul).

Kaya, S. (2012). The expectations of parents of primary school 1st grade students from the school and the level of meeting their expectations (Master's thesis, Yeditepe University, Istanbul).

Kiliçaslan, H. (2011). Perceptions of administrators and teachers towards the institutional image of primary schools: The case of central district of Bolu province (Master's thesis, Social Sciences Institute, Abant İzzet Baysal University, Bolu).

Lincoln, Y. S., \& Guba, E. G. (2013). The constructivist credo. California, CA: Left Coast Press.

Merriam, S. B. (2018). In S. Turan (Trans. and Ed.), A guide to qualitative research design and practice. Ankara: Nobel Publications.

Nartgün, S., \& Kaya, A. (2016). Creating School Image in Accordance with Private School Parents' Expectations. Journal of Research in Education and Teaching, 5(2), Article No. 17.

Özday1, N. (2004). Through the Eyes of Students and Teachers Classroom Management an Overview of Issues (pp. 375-394). XII. 1 Educational Sciences Congress, Gazi University Institute of Educational Sciences, Ankara.

Özenç, M. (2013). Determination of Levels of Primary School Teachers' Alternative Assessment and Evaluation Knowledge. Journal of Dicle University Ziya Gökalp Faculty of Education, 21, 157-178.

Özkan, U. (2018). Management of Secondary School Student Parent Class expectations (Non-Thesis Master's Project: Denizli-S6-26, Institute of Education Sciences, Department of Educational Sciences, TC Pamukkale University).

Patton, M. Q. (2014). In M. Tüm \& S. B. Demir (Trans. and Eds.), Qualitative research and evaluation methods. Ankara: Pegem Academy.

Pehlivan, K. B. (2004). The relationship between primary school teacher candidates' attitudes towards the teaching profession and school attitudes. Journal of Educational Research, 14, 211-218.

Seferoğlu, S. S. (2015). Technology use and applications in schools: Observations, problems and solutions. Plus, Education, 123, 90-91. Retrieved May 15, 2021, from http://www.egitim tercihi.com/okulgazetesi/17207-okullarda-teknoloji-olsun-m-ve-uygulamalar.html

Shenton, A. K. (2004). Strategies for ensuring trustworthiness in qualitative research projects. Education for Information, 22, 63-75. https://doi.org/10.3233/EFI-2004-22201

Tansel, A. (2002). Determinants of school attainment of boys and girls in Turkey: Individual, household and community factors. Economics of Education Review, 21, 455-470. https://doi.org/10.1016/S0272-7757(01)00028-0

Tansel, A., \& Bircan, F. (2006). Demand for education in Turkey: A tobit analysis of private 


\section{Macrothink}

tutoring expenditures. Economics of Education Review, 25, 303-313. https://doi.org/10.1016/ j.econedurev.2005.02.003

Tarhan, O. (2015). Opinions of social studies teacher candidates on political literacy. Journal of Academic Social Research, 9, 649-69. https://doi.org/10.16992/ASOS.538

Tinmaz, M. (2000). Effectiveness of public and private sector primary school administrators (Istanbul province example) (Unpublished Master's thesis, Sakarya University, Sakarya).

Treslan, D. L. (2008). Educational Supervision in a Transformed School Organization (Faculty of Education, Memorial University of Newfoundland, St. Jhon's).

Tümkaya, S., \& Asar, C. (2017). Examination of Primary School Administrators' Views on their Competencies. C.U. Journal of the Social Sciences Institute, 26(1), 242-253

Türnüklü, A. (2000). A qualitative research technique that can be used effectively in educational research: Interview. Journal of Educational Administration in Theory and Practice, 6(4), 543-559.

Ünsal, S., \& Cetin, A. (2019). Differences encountered by classroom teachers working in private and public schools in applying the curriculum. Kastamonu Education Journal, 27(4), 1541-1551. https://doi.org/10.24106/kefdergi.3131

Uysal, A. (2001). Management and leadership behaviors of primary school principals (Unpublished Master's thesis, Yıldiz Technical University, Istanbul).

Yenilmez, K., \& Özbey, N. (2006). A Research on Mathematics Anxiety Levels of the Students of Private School and the Other Schools. Journal of the Faculty of Education, 19(2), 431-448.

Yıldırım, A., \& Şimşek, H. (2011). Qualitative research methods in the social sciences (8th ed.). Ankara: Seçkin Publishing House.

\section{Copyright Disclaimer}

Copyright for this article is retained by the author(s), with first publication rights granted to the journal.

This is an open-access article distributed under the terms and conditions of the Creative Commons Attribution license (http://creativecommons.org/licenses/by/3.0/). 